\title{
14. Industrial relations, social dialogue and the transformation of the world of work: The Swedish experience*
}

\section{Dominique Anxo}

\section{INTRODUCTION}

A fundamental feature of the Swedish model is the crucial role played by the two sides of industry in shaping the norms that regulate the labour market: working conditions and wage formation. Essentially bipartite, social dialogue in Sweden is well developed and based principally on collective bargaining between strong and independent social partners. There are few tripartite institutions in Sweden, and both substantive agreements and procedural rules are the outcome of negotiated, bipartite self-regulation that is independent of state intervention. State intervention in the labour market does occur through labour legislation and employment policy, but a characteristic of the Swedish industrial relations system is that most labour laws can be modified via collective agreements, reinforcing the social partners' role in producing norms and rules regulating the labour market. Just because the Swedish industrial relations system is based predominantly on bipartite self-regulation, trust and cooperation between the social partners, as well as on autonomous collective bargaining, does not mean, however, that social dialogue between public authorities and the social partners is absent. Consultation and concertation between the latter have a long tradition, for example, in the form of government and parliamentary inquiries or committees, and they are an important element of Swedish industrial relations, influencing the design of employment, training and social policies. Government policy and attitudes towards social dialogue also affect the development of industrial relations.

Recent developments in the Swedish industrial relations system and social dialogue - in particular the emergence of new compromises regarding the organization of collective bargaining and the resolution of labour market conflicts, as well as changing power relations between the two sides of industry over the past two decades - are closely related to policy and institutional reforms. The reorientation of macroeconomic policy (fiscal consolidation and non-accommodative monetary policy), the waves of deregulation in labour and product markets, and modifications in the tax and benefit system, in particular the unemployment insurance system, have influenced the Swedish industrial relations system and may explain the significant decline of union density and the shift in the balance of power to the advantage of the employers.

This chapter is structured as follows. Section 2 describes the main features of the Swedish industrial relations system, the nature of the collective bargaining and social 
dialogue system, and reasons for its resilience, and then presents some outcomes of the industrial relations system. Section 3 sets out the recent transformations in Swedish industrial relations, focusing on the trends in trade union and employer density, as well as changes in the level of collective bargaining. Section 4 illustrates the impact on the Swedish industrial relations system of policy reforms and institutional changes, with a special focus on the reform of unemployment insurance (Ghent system) in explaining recent developments (Case Study 1). Furthermore, a short description is given of strategies used by trade unions to counteract declining membership and union density. Section 5 analyses the attitudes and role of social partners and public authorities as regards restructuring and technological changes in general, and information technology (IT) and digitalization in particular (Case Study 2). The final section offers some concluding remarks.

\section{SWEDISH INDUSTRIAL RELATIONS SYSTEM AND SOCIAL DIALOGUE $^{1}$}

\subsection{Triad of Swedish Industrial Relations: Autonomy, Strength and Self-regulation}

The Swedish industrial relations system relies on powerful, independent and allencompassing employers' and workers' organizations that enjoy substantial autonomy vis-à-vis the public authorities (see Anxo 2018, 2019). The Swedish industrial relations system, and therefore social dialogue, constitutes the archetype of a bipartite agreementbased model of labour market governance, in which the social partners play an essential role in determining the norms and mechanisms for regulating the labour market, as well as the employment relationship (working conditions and wage formation). ${ }^{2}$ This tradition of self-regulation as regards not only labour market norms, but also procedural rules regulating conflicts and collective bargaining, is based on voluntary collective agreements, not agreements enforced by law. As noted by Kjellberg (2017), the only way to oblige employers to enter collective agreements is through collective action.

Despite a notable decline since the early 1990s, union density in Sweden remains the highest among advanced economies (see Kjellberg 2019c; Visser 2019), at around 68 per cent in 2018 (63 per cent in the private sector and 79 per cent in the public sector; see Table 14A.2 in the appendix at the end of this chapter). The coverage rate of collective agreements stood at around 90 per cent in 2017 (84 per cent in the private sector and 100 per cent in the public sector (see Kjellberg 2019b; LO 2019; Mediation Office 2019; Table 14A.6 in the appendix). In the private sector, the coverage rate of collective bargaining is higher among manual workers than among white-collar workers (95 per cent compared with 75 per cent, respectively; see Table 14A.7 in the appendix). It is important to stress that the high coverage rate of collective bargaining in Sweden is not owing to statutory extension of collective agreements, but to the high affiliation rate of employers' associations and the strong presence of trade unions at the firm or organization level. Note also that the provisions set out in collective agreements apply even to employees who are not union members.

Sweden is therefore characterized not only by powerful unions, ${ }^{3}$ but also by wellestablished and strong employers' organizations. ${ }^{4}$ In 2017 , the density rate of employers' 
organizations, that is, the share of dependent employees in workplaces affiliated to employers' associations and covered by a collective agreement, reached 88 per cent, a rate significantly higher than union density (see Kjellberg 2019c; Table 14A.5 in the appendix).

In contrast to some other EU member states, wage-earners are represented by local union clubs and not by separate works councils. Union representatives at the workplace also have a mandate to negotiate. In the early 1970s, the adoption of several labour laws reinforced the influence and bargaining power of union representatives at the company or organization level and restricted employers' unilateral right to manage. The Act on Union Representatives Position at the Workplace (SFS 1974, p. 358) stipulates that an employer may not prevent trade union representatives from performing their duties. Trade union representatives are entitled to time off, and the employer has to provide premises at the workplace for the performance of trade union duties. Furthermore, the Act specifies that trade union representatives shall not be subjected to worse working conditions or terms of employment as a result of their appointment.

The second law, adopted in 1976, strengthening the influence of trade union at the company level, is the Law on Codetermination in Working Life (SFS 1976, p. 580). This Act stipulates that, prior to any decision regarding significant changes in employment and working conditions, employers are obliged to inform and consult the trade union organization(s) in charge of concluding collective agreements. Should the employees' organization so request, an employer has to negotiate with that organization before implementing decisions concerning, among other things, restructuring, collective dismissal and substantial changes in employment and working conditions.

With some exceptions, employers' and workers' organizations in Sweden are structured along sectoral or industry lines. Despite some tendencies towards decentralization during the past two decades, the Swedish bargaining system remains fundamentally two-tier, in which bargaining takes place first at the industry level and then at the company/organization level. It is important to emphasize that, by international standards, the Swedish two-tier bargaining model remains centralized and coordinated, and that the articulation between the industry and company level is regulated by the social partners.

Another central feature of the Swedish industrial relations system is that the role of labour legislation is limited by comparison with labour legislation in other EU member states, and for the most part is optional; that is, most provisions of labour market legislation may be wholly or partly amended by collective agreements. An illustration of the interplay between statutory policy and contractual arrangements is the Employment Protection Act (SFS 1982a, p. 80). According to the law, seniority rules mean that employee priority and selection are based on the last-in-first-out principle. However, the employer and the trade unions may deviate from the statutory rules when determining the order of dismissals by concluding a local collective agreement. Another illustration of the optionality of labour law and the predominant role of social partners in regulating working conditions concerns working time. The Swedish Working Hours Act (SFS 1982b, p. 673) appears to be particularly flexible and has, since the late 1950s, also left the social partners free to negotiate and draw up industry-wide agreements on working hours. Hence, the Working Hours Act is also optional and can be partly or entirely replaced through collective agreements at the industry and/or plant level. In addition to protecting individuals not covered by collective bargaining and limiting the negative externalities 
coupled with longer hours, the optional nature of the law has encouraged the social partners to negotiate flexible working-time arrangements at the industry or firm level.

Collective agreements also often supplement social security regulations, such as a higher income replacement rate for parental leave or sickness benefits. Another illustration of the social partners' involvement in social protection is the unemployment insurance system. The Swedish unemployment insurance system is a Ghent system based on voluntary membership in unemployment insurance funds subsidized by the state. These funds are administered by different trade unions covering different industries. The Ghent system of unemployment insurance is often used to explain the relatively high union density in Sweden. It should be noted, however, that employees may choose to be affiliated to an unemployment insurance fund without being a trade union member. To illustrate the impact of policy changes on the autonomy, strength and bargaining power of the two sides of industry, in section 3 we explore the consequences of the reform of the unemployment insurance system initiated in 2006 by the liberal-conservative coalition government for the development of industrial relations and union density.

\subsection{Tripartite Social Dialogue in Sweden}

There are no legal obligations in Sweden governing consultations between the government/ public authorities and the social partners. However, tripartite talks or consultations have a long tradition, are well established and are a key element in government employment and social policies. ${ }^{5}$ The social partners are usually represented or consulted in parliamentary and government committees responsible for drawing up employment, education or training and social policies. Thus, the social partners exert significant influence on the contents of labour market legislation. Even though consultations and informationsharing concerning labour market issues between government, parliament and both sides of industry are a common feature of the political and legislative process, the nature of industrial relations and social dialogue in Sweden remains mainly bipartite. The state is involved in social dialogue in its capacity as employer at the central and local authority levels, but this takes place through the respective employers' associations ${ }^{6}$ and workers' organizations in the public sector.

A recent illustration of tripartite consultations or concertation concerns the integration of newly arrived refugees into the Swedish labour market. While Sweden has been very successful in integrating women, the elderly and those with a work disability into the labour market, the country has been singularly less successful in integrating people with an immigrant background. ${ }^{7}$ The situation of migrants on the Swedish labour market has deteriorated over the past two decades and remains a challenge. Against this background, in 2015 the government launched a first round of tripartite talks, with particular focus on the integration of newly arrived refugees and migrants in the labour market, which led to the conclusion of several fast-track agreements between the Swedish Public Employment Agency (PEA, Arbetsförmedlingen) and the social partners. The fast-track initiative involved early validation and assessment of education and professional skills according to industry-specific agreements. The overall aim of these tripartite talks and agreements was to better identify and assess at an early stage the skills of newly arrived migrants with education or experience in occupations facing a labour shortage, so that they could be matched more quickly with the needs of industry and companies. The Swedish PEA 
initiated closer collaboration with the social partners and relevant government agencies ${ }^{8}$ on creating fast tracks in several sectors (forestry and agriculture tourism, health and medical care, local government, industry, health and social care, transport, painting, timber and graphics companies, real estate, energy and electronics, and building) and specific occupations (such as agronomists, nurses and assistant nurses, doctors and dentist, teachers, machine operators, mechanics, social scientists and social workers).

Another recent example of tripartite talks and concertation concerning the introduction of new technologies, and their impact on the world of work, is given in section 5 (Case Study 2).

\subsection{Main Factors Explaining the Strength and Autonomy of Trade Unions and Employer Organizations}

The main objective of this section is to identify the main institutional factors explaining Sweden's good performance regarding its industrial relations system and social dialogue, and the persistence and resilience of a bipartite agreement-based model of labour market regulation. As stressed by Kjellberg (2017, 2019a), the Swedish system, characterized by voluntarism, self-regulation and bipartite social dialogue, relies on high union and employer association density, promoting high coverage of collective agreements.

Several factors, contextual and institutional, explain the strength and autonomy of trade unions and employer organizations in Sweden. First, the autonomy and independence of the social partners are related to the source of financing of trade unions and employer organizations, based on fees paid by union members and affiliated companies, without financial support from the state. High union membership (see Table 14A.1(a) in the appendix) ensures solid financial resources and union autonomy, as well as strengthening their bargaining power, their capacity for action and their legitimacy. The high proportion of firms affiliated to employer organizations (see Tables 14A.4 and 14A.5 in the appendix), in particular medium-sized firms and large multinational companies, which employ more than 85 per cent of employees in Sweden, explains the high coverage of collective bargaining, reinforcing the crucial role of social partners in shaping working and pay conditions.

The positive attitudes of the two sides of industry towards the prevailing two-tier bargaining system of labour market regulation, based on collective agreements at the industry and company or organization level and their mutual reluctance to accept state intervention in wage setting, ${ }^{9}$ is explained by the social partners' belief that bilateral social dialogue and a two-tier bargaining system are more efficient and flexible, allowing the two sides of industry to reach agreements that are more in line with employees' demands regarding wage and working conditions, and are better adapted to industry and local production constraints and competitiveness.

The relatively high centralization and coordination of collective bargaining, coupled with collective agreements at the industry or company or organization level applying even to non-union members, largely explain the dominant role played by collective agreements in shaping labour market norms. In this context, the tendency towards re-coordination of collective bargaining in the mid-1990s is an important factor explaining the resilience of the Swedish industrial relations system. During the 1980s, the weakening of mechanisms for coordinated collective bargaining, the resurgence of industrial disputes, the threat 
of state intervention, high wage inflation and the dramatic increase in unemployment during the recession of the early 1990s all had a decisive impact on the emergence of new compromises for industrial relations. The three main trade unions ${ }^{10}$ in the sectors exposed to international competition asked their employer counterparts to consider the possibility of setting up new procedural rules that fostered both industrial peace and wage increases guaranteeing balanced growth and a return to full employment. The ensuing talks culminated in the adoption of an Industry Agreement on Cooperation on Industrial Development and Salary Formation in 1997 (Industriavtalet). One of the main innovative features of the Industry Agreement, apart from its tendency to re-coordinate collective bargaining, is that it explicitly regulates the conduct of negotiations and the resolution of disputes. If there is any risk of industrial action, the social partners concerned are obliged to notify the impartial chairs before the start of the notice period for a strike or lockout. These changes in industrial relations also re-established the pace-setting role of the sectors exposed to international competition, by establishing a wage norm in line with productivity developments, which should also apply to all other bargaining areas. In this context, the coordination role of the LO confederation has been increasing for LO affiliates in order to ensure that the new industry wage norm is respected.

It should also be stressed that the consensual nature of social dialogue in Sweden ${ }^{11}$ and the root of the Swedish model does not rely on a specific cultural legacy, an idiosyncratic mentality favouring consensus and compromise, but relies more on the strength and relative balance of power between the two sides of industry, as well as the explicit negotiated procedural rules regarding the code of conduct between social partners and the organization of collective bargaining. To illustrate, the historical compromise of 1938, the Saltsjöbaden Agreement, ${ }^{12}$ paving the way for almost 40 years of peaceful industrial relations in Sweden, was concluded in a period characterized by social unrest and threats of state intervention. From the end of the nineteenth century up to the second half of the 1930s, Sweden had the highest incidence of labour market disputes (strikes and lockouts) in Europe. As noted above, the Industry Agreement was also concluded during a period of frequent industrial disputes (see Anxo 2018) and the threat of state intervention. That is, these agreements are a good illustration of the social partners' willingness to retain their autonomy vis-à-vis public authority, and to safeguard a system of labour market regulation and governance based on bipartite social dialogue and collective agreements.

Another important feature of the Swedish industrial relations system is that Swedish labour law does not contain rules on union recognition, but several laws were adopted during the 1970s limiting de jure and de facto employers' unilateral prerogative to manage and reinforcing the bargaining power of trade unions at the company or organizational level. ${ }^{13}$ The high representativeness of trade unions at the workplace level, coupled with local union representatives having a mandate to negotiate, also explain the high union density in Sweden. Contacts between union representatives and employees at the workplace level favour the formulation of local union strategies in line with the demands of their members and ease the communication of results. The strong presence of trade unions at the firm or organization level also facilitates the recruitment and retention of union members.

The independence, or autonomy, and bargaining power of unions rely heavily on voluntary union membership and their mobilization capacity. To maintain high union density is therefore crucial for trade unions' legitimacy, autonomy, bargaining strength 
and long-term sustainability. As stressed by Kjellberg (2019c), although collective agreements apply even to non-union members, this does not constitute an incentive to join a union (free-rider issue). Therefore, unions have to develop strategies in order to encourage employees to join and stay. Collective agreements at the industry level, and even at the company level, often extend and improve the statutory universal basic social protection in the form of higher replacement or compensation rates, or longer periods of entitlement, for example, regarding unemployment and sickness benefits, parental and training leaves and (occupational) pensions. That is, the role of the social partners is not limited to the regulation of the labour market in a strict sense, but extends to the realm of social protection via collective agreements and specific insurance restricted to union members (see Sjögren-Lindquist and Wadensjö 2006). This supplementary insurance reserved to union members constitutes an important incentive to join a union, and is a contributory factor explaining the high union density in Sweden. Another advantage of membership is the provision of legal services and support in case of conflicts or disagreements with employers.

If the services, benefits and protection or insurance against labours market-related risks provided by trade unions explain the relatively high union density in Sweden, strong support, the positive attitude of employees and workers' conviction that the unions defend workers' interests might also be a factor. According to the Organisation for Economic Co-operation and Development (OECD 2019), Sweden, after Denmark, has the highest level of population (aged 20-54) trust in trade unions (more than 80 per cent in 2018). ${ }^{14}$

\subsection{Outcomes}

With its developed social dialogue, Sweden has high employment rates, ${ }^{15}$ high job quality and low inequality not only in relation to wages and income, but also regarding equal opportunities, such as access to training or education, the labour market and social protection. To a considerable extent, this situation and Sweden's good employment record can be ascribed to its institutional setup, in particular its industrial relations system.

The contractual nature of labour market regulations and governance, coupled with the high union density and high collective bargaining coverage rate, creates an institutional environment favouring the emergence of negotiated compromises aimed at balancing flexibility and security in the labour market. Sweden thus constitutes a good illustration of a regime of negotiated flexibility, in which the social partners are involved extensively in regulating working conditions, wage formation and the shaping of vocational training at the industry and company or local levels. By international standards, wage and income inequality is low in Sweden. In 2016, Sweden had the lowest share of low-wage earners ${ }^{16}$ among EU member states (only 2.6 per cent compared with 17.2 per cent for the whole EU). Despite a tendency to rising wage dispersion since the mid-1990s, the Swedish wage structure remains compressed. The lower wage dispersion in Sweden, one of the lowest among OECD countries (see Paccagnella 2014) can be ascribed to a series of interrelated factors: the centralized and coordinated wage-bargaining system, limiting wage disparities between firms and industries, relatively high collectively agreed wage floors and, last but not least, the strong bargaining power and implantation of Swedish trade unions, at both the industry and company levels, favouring a more balanced outcome regarding 
wage structure and wage development. This more balanced outcome is not limited to wage structure but also concerns working and employment conditions. The role of the social partners is also central in connection with lifelong learning, training facilities and occupational mobility, as illustrated by their active involvement in the shaping of traditional (passive and active) labour market policies (see also section 4 and the job transitional agreements).

The compressed wage structure, with high collectively agreed wage floors, has also promoted productivity-enhancing structural changes, limited the development of low-paid or low-skilled jobs and contributed to the development of a high-skilled, knowledgeintensive workforce. Large investment in labour saving technologies and research and development and the associated increase in demand for high-skilled jobs, ${ }^{17}$ the welldeveloped lifelong learning and training system, the expansion of tertiary education during the past three decades, as well as a more balanced bargaining power between the two sides of industry, have limited the tendency towards job polarization found, for example, in liberal market-orientated economies.

As far as working time - a central element of working conditions - is concerned, compared with the EU as a whole, Sweden displays a higher concentration of wage earners around the 40-hours norm and a lower dispersion of working time, with a lower incidence of marginal part-time work and longer working hours. These are strong reasons for believing that the higher concentration around the 40 hours-norm is related to the high degree of coordination and centralization of collective bargaining in Sweden. The weaker (gender) polarization of working time can be ascribed to several factors: the low incidence of low-paid jobs (the lowest in the EU), limiting the incidence of long working hours, legal enforcement of collective agreements, and more favourable gender contract and work-life balance arrangements.

In summary, the bipartite contractual nature of Swedish social dialogue and the balance of power between the two sides of industry largely explain the country's good performance regarding job quality and fair working conditions, equal opportunities and wage inequalities, even though some challenges remain, in particular regarding the labour market integration of newly arrived migrants.

\section{RECENT DEVELOPMENTS IN THE SWEDISH INDUSTRIAL RELATIONS SYSTEM: THE SIGNIFICANT DECLINE OF UNION DENSITY}

Even though Sweden still has the highest union density in the EU, it has experienced a significant decline in its union membership and density over the past three decades. Several factors help to explain falling union membership in Sweden, with a decline of almost 15 percentage points between 1990 and 2018 (see Figure 14.1, and Tables 14A.3 in the appendix). Parallel to this development the coverage rate of collective agreements has also shown a tendency to decline, from 94 per cent in 1995 to 89 per cent in 2017 (see Table 14A.6 in the appendix).

It is important to distinguish long-term factors, related principally to major changes in employment and occupational structure, from short-term factors, linked to specific policy measures. In particular, the long-term reduction of employment in manufacturing 


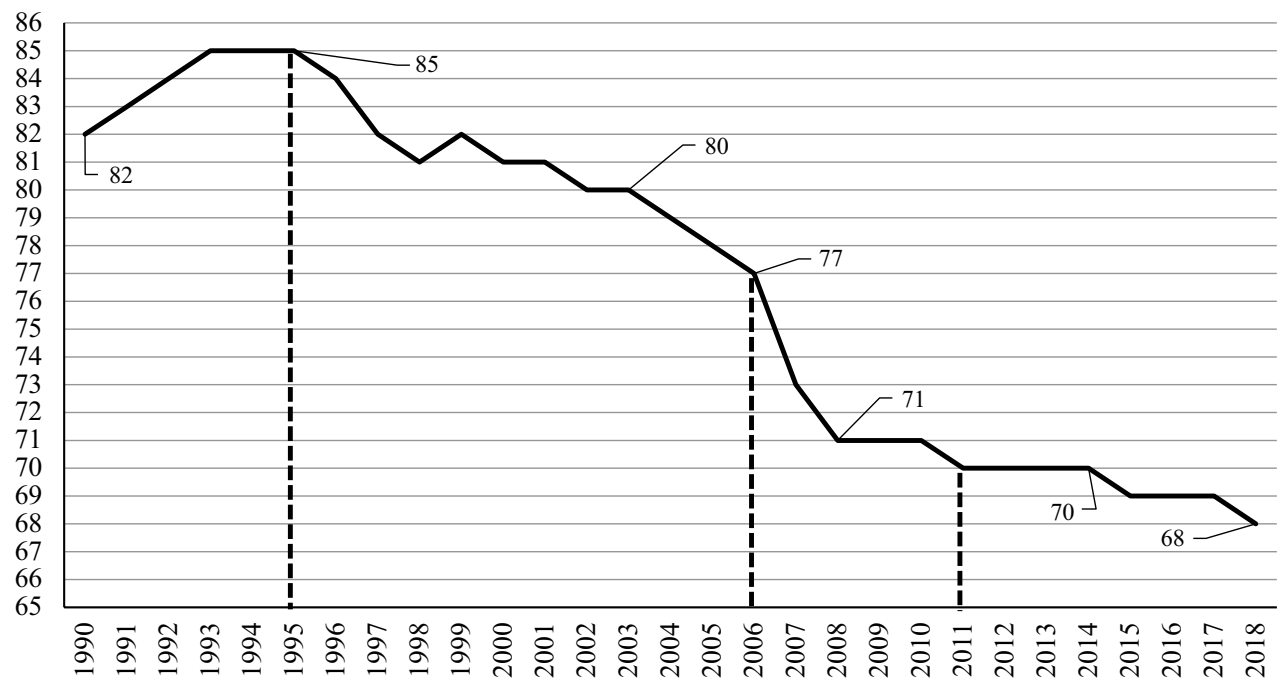

Source: Kjellberg (2019c) and Mediation Office (2019).

Figure 14.1 Union density, 1990-2018 (percentage)

industry owing to restructuring and rationalization, and the decline of employment in the public sector ${ }^{18}$ owing to fiscal consolidation measures, waves of deregulation and privatization in the service sector initiated in the 1990s, combined with changes in societal norms (individualistic values), explain part of the long-term decline in membership and union density. The fall in membership (and union density) has been particularly marked among manual workers (LO members; see Figure 14.2, and Table 14A.3 in the appendix). For white-collar workers, membership has been increasing, especially among the highskilled or highly educated (principally members of Saco unions), reflecting the changes in employment and skill structure in recent decades. Looking at the distribution of membership by confederations (see Table 14A.1b in the appendix), in 1975, LO members accounted for around 65 per cent of all union members, but for only 40 per cent in 2018 . As further shown by Tables 14A.1(a) and 14A.1(b) in the appendix, during the same period, the number of Saco members increased by around 280000 , whereas its relative share went up from 4 per cent to 19 per cent between 1975 and 2018.

The successive reforms of the employment protection system in Sweden, in particular the introduction of short-term contracts not requiring justification from the employer, combined with the deregulation of employment intermediation in the early 1990s and the associated expansion of temporary agency work, have contributed to a significant increase in employment instability and a growing duality in the labour market between insiders and outsiders.

The rise of short-term contracts and the increasing use of temporary agency and self-employment work has also contributed to the decline of union density in Sweden; union density is significantly lower among people on fixed-term contracts compared with those on open-ended contracts ( 44 per cent versus 72 per cent, respectively, in 2018; see Table 14.1). Over the past few decades, union density among short-term contacts 


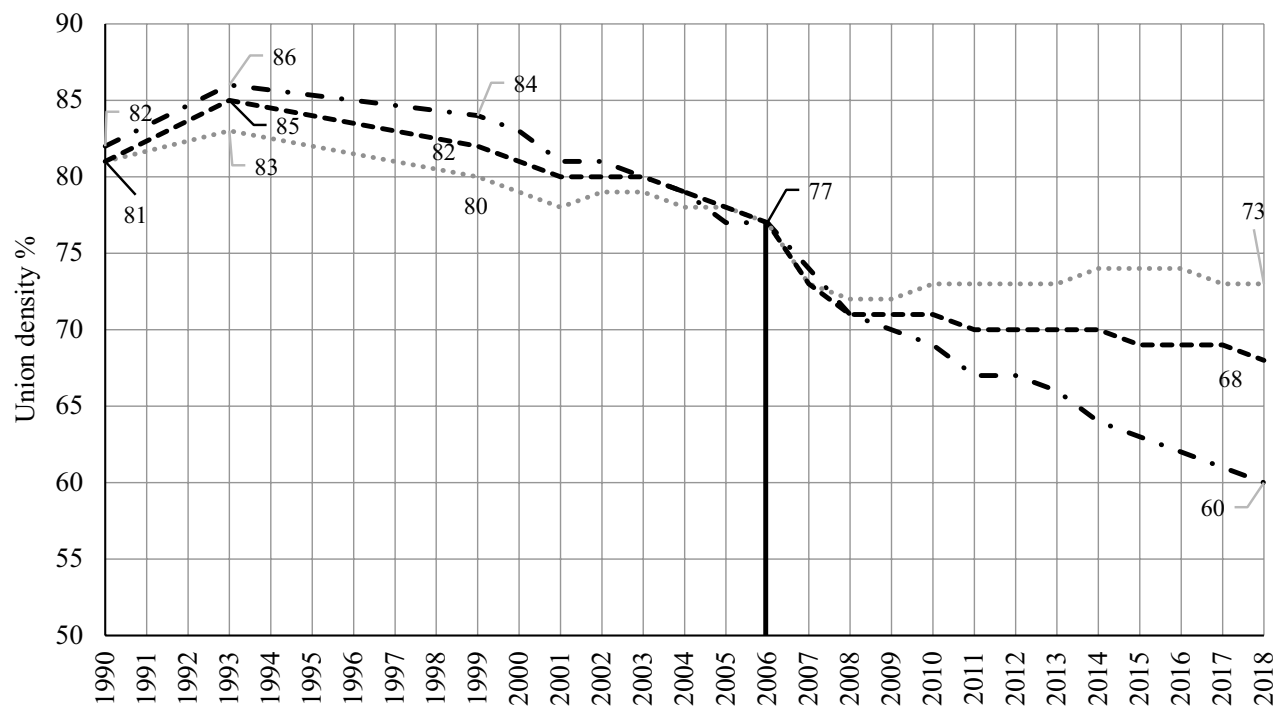

_ - Manual/blue-collar workers ....... Non-manual/white collar workers _ _- All

Source: Kjellberg (2019c).

Figure 14.2 Union density by category of employees, 1990-2018 (percentage)

has declined significantly more than for open-ended contracts. Between 2005 and 2018, among manual workers, the drop in union density amounted to 23 percentage points for fixed-term contracts compared with 16 percentage points among open-ended contracts (the corresponding figures for white-collar workers during the same period were 16 and 5 percentage points, respectively).

The negative trends in union density have been particularly marked among young people aged 16-29 (a decline of around 20 percentage points compared with 11 percentage points for adults between 1990 and 2018) and among the foreign born (a drop of 16 percentage points compared with 6 percentage points for natives, over the past ten years; see Table 14.2).

These two socio-demographic groups are often over-represented among short-term contracts, jobs with unsocial hours and in low-paid industries with low union density

Table 14.1 Union density by type of employment contract, Sweden, 2005-18

\begin{tabular}{lccccccccr}
\hline $\begin{array}{l}\text { Type of } \\
\text { contract }\end{array}$ & $\begin{array}{c}\text { Open } \\
\text { ended }\end{array}$ & $\begin{array}{l}\text { Fixed } \\
\text { term }\end{array}$ & All & $\begin{array}{c}\text { Open } \\
\text { ended }\end{array}$ & $\begin{array}{l}\text { Fixed } \\
\text { term }\end{array}$ & All & $\begin{array}{c}\text { Open } \\
\text { ended }\end{array}$ & $\begin{array}{l}\text { Fixed } \\
\text { term }\end{array}$ & All \\
\hline 2005 & 83 & 63 & 80 & 80 & 68 & 79 & 81 & 61 & 78 \\
2010 & 76 & 43 & 71 & 75 & 58 & 73 & 74 & 48 & 71 \\
2018 & 67 & 37 & 62 & 75 & 53 & 73 & 72 & 44 & 68 \\
\hline
\end{tabular}

Source: Kjellberg (2019c). 
(hotels and restaurants, transport; see Table 14A.3 in the appendix for union density by broad industries), which also explains the negative trends in union density. Regarding gender disparities, union density is higher among women (72 compared with 64 per cent in 2018) and decreased less than for men in the period 1990-2018 (11 compared with 16 percentage points; see Table 14.2).

Even though structural factors and compositional effects explain the long-term decline of union density in Sweden, the acceleration of this decline after 2006 is closely related to specific policy measures, in particular the reform of the unemployment insurance system initiated by the centre-right government in 2007 (see Case Study 1 in the next section) and the abolition of the tax deductibility of union fees by the right-wing government between 2007 and 2017. The tax deduction of union fees was temporary reintroduced by the Social Democrats in 2018, but abolished again in 2019 by the same government under pressure from the right-wing dominated parliament.

The decline in trade union membership and the related change in the balance of power between the two sides of industry has hitherto had a limited impact on the development of wages and working conditions, as well as the wage-profit share of gross domestic product (see Anxo 2018). However, if this downward trend in union density continues at the same pace, ${ }^{19}$ we cannot exclude that the associated decline in the bargaining power of trade unions will negatively affect the outcome of social dialogue in Sweden, leading to a continuous erosion of the Swedish industrial relations system and the long-term sustainability of the Swedish model.

Table 14.2 Union density by age, gender and ethnicity, Sweden, 1990-2018 (percentage)

\begin{tabular}{lccccccccc}
\hline & 1990 & 2000 & 2006 & 2008 & 2010 & 2015 & 2018 & $\begin{array}{l}\text { Var. 2018/1990 } \\
\text { percentage } \\
\text { points }\end{array}$ & $\begin{array}{l}\text { Var. 2018/2006 } \\
\text { percentage } \\
\text { points }\end{array}$ \\
\hline Age & & & & & & & & & \\
$16-24$ & 62 & 52 & 46 & 36 & 34 & 35 & 36 & -26 & -10 \\
$25-29$ & 78 & 74 & 68 & 61 & 60 & 59 & 58 & -20 & -10 \\
$30-44$ & 85 & 82 & 77 & 72 & 73 & 70 & 68 & -17 & -9 \\
$45-64$ & 88 & 88 & 85 & 81 & 80 & 79 & 77 & -11 & -8 \\
$16-64$ & 81 & 81 & 77 & 71 & 71 & 69 & 68 & -13 & -9 \\
\hline Gender & & & & & & & & & -10 \\
Men & 80 & 78 & 74 & 68 & 68 & 66 & 64 & -16 & -8 \\
Women & 83 & 83 & 80 & 74 & 75 & 73 & 72 & -11 & -6 \\
\hline Ethnicity & & & & & & & & & -16 \\
Natives & - & - & 77 & 72 & 72 & 71 & 71 & - & \\
Foreign born & - & - & 74 & 67 & 67 & 61 & 58 & - & \\
\hline
\end{tabular}

Source: Kjellberg (2019c). 


\section{CASE STUDY 1: INDUSTRIAL RELATIONS SYSTEM AND INSTITUTIONAL CHANGES: REFORMS OF THE UNEMPLOYMENT INSURANCE SYSTEM}

\subsection{Reforms of the Unemployment Insurance System and the Significant Decline of Union Density in Sweden}

Even though structural factors and compositional effects explain the long-term decline of union density in Sweden, the acceleration of this decline after 2006 is closely related to policy measures, in particular the reform of unemployment insurance initiated by the centre-right government in 2007 and 2008. This reform resulted in a notable reduction in the generosity of the Swedish unemployment insurance system: the income replacement rate fell from 80 per cent to 70 per cent after 200 days of unemployment, and the maximum duration for receiving unemployment benefits was reduced to 300 days. Furthermore, the financing of unemployment insurance was modified: the contributions of the various unemployment funds administered by the trade unions (Ghent system ${ }^{20}$ ) were dramatically increased and differentiated according to the unemployment level in the sector or industry concerned. That is, a system of experience rating was introduced, and individual unemployment insurance contributions increased or decreased depending on whether unemployment grows or declines in an industry. This reform entailed a large rise in individual monthly contributions; in some instances, unemployment insurance fees paid by individuals tripled. ${ }^{21}$ The consequence was both a large decrease in union membership and a dramatic decline in the number of dependent employees covered by the unemployment insurance system: around 500000 employees left the system between 2007 and 2008. ${ }^{22}$ As reported by Kjellberg (2015), the decline of union density in the aftermath of the unemployment insurance reform was unprecedented and, as a whole, dropped by 6 percentage points (from 77 per cent in 2006 to 71 per cent in 2008). The main objectives of the centre-right government with these unemployment insurance reforms were to enhance job seekers' work incentives and to indirectly influence the outcome of wage bargaining by weakening trade union bargaining power, and thereby to induce wage restraint.

The 2008 financial crisis particularly hit sectors exposed to international competition and blue-collar workers. Against this background, the reform of unemployment insurance financing had a stronger impact on union density among LO members, in particular in low-skilled and low-paid sectors, such as hotels and restaurants and retail, with high labour turnover and large shares of short-term contracts, but also in manufacturing industry. There are therefore strong reasons to believe that a significant part of the recent decline of union density in Sweden was a consequence of this reform.

Also worth noting is that while the 2008 great recession did not break the fall of union density among blue-collar workers ${ }^{23}$ the reverse is true for white-collar workers. While unemployment insurance reform also affected the latter between 2007 and 2009, their union density increased again in the aftermath of the crisis, reaching about the same level as in 2006 (see Table 14A.3 in the appendix). In early 2014, the centre-right coalition government again changed the rules on unemployment insurance financing, restoring individual monthly unemployment insurance fees to their 2006 level. ${ }^{24}$ Nevertheless, the number of unemployment insurance members has increased again in recent years, by 
almost 55 000, but it is still below its 2006 level. More recently, the Social DemocraticGreen coalition government, which took office in September 2014, increased the unemployment insurance income replacement rate. As indicated by Figures 14.1 and 14.2, these measures did not manage to halt the decline in union density among blue-collar workers. The measures initiated in 2014 and 2016 helped temporarily to stabilize the level of union density among white-collar workers, but union density has been falling again during the past two years.

\subsection{Trade Union Strategies to Counteract Falling Union Density}

Confronted by the significant decline in union membership and union density, trade unions have developed a range of strategies to reverse it. As shown by previous developments, the decline in union density has been particularly high among young people, low-skilled, low-paid workers, short-term contract workers and foreign-born workers. Against this background, trade unions have prioritized recruitment of new members among these vulnerable groups and are trying to reach individuals with a weaker attachment to the labour market. The trade unions have also prioritized activities at workplaces.

At the last LO congress, membership issues were to the fore and measures have been taken to counteract the decline in union density. In the LO Work Programme 2017-2020, entitled 'Organize or Die', one of the stated objectives was to restore a union density of 80 per cent. The LO strategy has been to recruit new members at the workplace level and stem the number of exits. Against this background, measures have been taken to support trade union representatives in the workplace. In order to counteract the falling youth membership, at the end of 2018, some LO federations decided to launch an information campaign at school level. Among white-collar unions, the TCO launched a big information campaign 'Membership Value and Union Transformation' targeted principally towards students and young academics. In order to broaden their recruitment base, some federations, within the confederations TCO and Saco, have opened membership to the self-employed and students. ${ }^{25}$ In recent years, several white-collar unions have also introduced supplementary income compensation, restricted to union members, in the event of unemployment or sickness, to counteract the increase of unemployment insurance fees and the worsening of unemployment benefits (duration and income replacement). Except for Saco, which has seen its membership increase significantly during the past decade, up to now the efforts of the LO and the TCO have not resulted in a significant improvement in membership and union density.

In summary, the marked decline in union membership and union density in Sweden among blue-collar workers threatens the representativeness and legitimacy of blue-collar unions, as well as their autonomy and bargaining power. This development, if it continues, endangers the long-term sustainability of the Swedish model of industrial relations and its ability to reconcile efficiency and social justice. As shown by previous developments, the decrease in union density can be ascribed to policy reforms, the weakening of the Ghent system of unemployment insurance and to major changes in the world of work, particularly the rise of precarious employment related to the change in employment protection and labour market deregulation. Against this background, trade unions in Sweden have taken several measures to broaden their recruitment base, trying to reach low unionized vulnerable groups and non-standard forms of employment (short-term 
contracts, temporary agency workers, solo self-employed and digital platform workers). In order to attract and keep members, unions have also developed new services and have made more use of digital technologies to communicate with and reach new members (Facebook and Twitter). Furthermore, in order to limit the negative impact of erga omnes practices on union membership (free-rider problems), several trade union federations have introduced complementary insurance schemes (sickness and unemployment) that are restricted to union members. Except for high-skilled, white-collar workers, who have experienced an increase in union density during the past decade, the efforts of the LO and the TCO to date have not significantly improved membership and union density.

\section{CASE STUDY 2: ACCOMMODATING STRUCTURAL AND TECHNOLOGICAL CHANGES: THE CENTRAL ROLE OF THE SOCIAL PARTNERS IN SWEDEN}

The Swedish industrial relations system, together with the bipartite contractual nature of labour market regulation, creates a favourable institutional environment for the emergence of negotiated compromises aimed at balancing flexibility and security in the labour market. This institutional environment has resulted in innovative practices and solutions for dealing with job losses, and structural and technological changes. Particularly notable are the creation, in the early 1970 s, of the job security/transitional job agreements that were established by the social partners on a bipartite basis to support employees and companies affected by restructuring.

\subsection{Overall Framework: Attitudes of Swedish Social Partners to Structural and Technological Change and the Role of Social Dialogue and Flexicurity Regime}

Sweden is a small open economy strongly exposed to international competition. Against this background, the strategy of the Swedish social partners has seldom been to safeguard jobs in declining low-productivity sectors or in industries confronted by severe restructuring. Instead they have favoured measures to uphold Sweden's competitiveness by boosting investment in workers' human capital (training or lifelong learning) and the introduction of productivity-enhancing technologies or rationalization. This explains why structural changes or economic downturns have seldom been accommodated by measures aimed at maintaining employment or favouring labour hoarding, for example, by work-sharing measures, as in France or Germany, or by a worsening of working conditions or wage cuts.

Traditionally, employment adjustments caused by structural and technological changes in Sweden have mainly taken the form of negotiated external numerical flexibility, ${ }^{26}$ combined with active support for dismissed workers through public active labour market policy programmes and/or bipartite negotiated job transitional agreements, helping redundant workers to find new jobs rapidly or by enhancing their employability through mainly training or skill-upgrading measures. Hence, the roles of social dialogue and collective bargaining in accommodating structural and technological changes are at the core, and the social partners play a key role in preserving Sweden's competitiveness and limiting the negative individual consequences of introducing new labour-saving 
and productivity-enhancing technologies (see Anxo 2017). The job security/transitional agreements constitute a good illustration of such negotiated flexicurity arrangements. In cases of collective redundancy owing to restructuring, or individual notice owing to a shortage of work, the Swedish social partners have, since the early 1970s, negotiated security/adjustment agreements to help displaced workers to find new jobs quickly, by way of adjustment measures ${ }^{27}$ and financial support. These support programmes are administered by the two sides of industry: the job security councils (trygghetsrädet) and job security foundations (trygghetsstiftelser), specially designed for this purpose. ${ }^{28}$ The support measures offered by the job security councils take several forms, including severance payments and complementary unemployment compensation above the standard unemployment benefit in order to guarantee a decent level of income during the transitional period. The job security councils play an important role at different stages in the restructuring process. In the initial stage of the process, counsellors provide the employer and trade union representatives with expertise related to the restructuring process. After the decision has been taken on which restructuring strategy to pursue, the second phase involves guidance and support to the employees affected by restructuring (see Anxo 2017).

By supplementing the role of local public employment agencies, these agreements, covering about 75 per cent of the labour force, help to improve employment security, promote efficient allocation of resources and have played an important role in accommodating economic restructuring and technological changes. Sweden is in this way unique, in that the social partners assume responsibility for an important part of restructuring.

The centralized and coordinated collective bargaining system and a still compressed wage structure, with relatively high wage floors, have also limited the development of low paid or low-skilled jobs in Sweden, and instead have boosted policies favouring skills upgrading. In effect, substantial investment in research and development and a well-developed lifelong learning and training system have limited the tendency towards job polarization found, for example, in liberal market-orientated economies. In this context, the Swedish job security councils and transitional job agreements have played a fundamental role in alleviating the detrimental individual consequences of structural and technological changes, in particular by limiting long periods of unemployment, which we know are a crucial determinant of social exclusion and increased inequality. These agreements are another good illustration of the prevailing regime of flexicurity and negotiated flexibility, combining individual security for employees and flexibility for employers in respect of necessary restructuring and readjustment measures. The joint management structure of the social partners appears also to be an advantage, reinforcing the social legitimacy as well as the positive attitude of Swedish trade unions towards structural and technological changes and productivity-enhancing restructuring.

\subsection{Digitalization and Tripartite Social Dialogue: Recent Developments in Sweden ${ }^{29}$}

In June 2012, the centre-right Swedish government set up the Digitalization Commission to analyse the impact of digitalization on Swedish society and the policy strategies that should be initiated in order to meet the new technological challenges. In February 2015 the newly elected Social Democratic government decided to amend the directive for the commission to identify strategic areas and to investigate how support in the area should 
be implemented. Tripartite talks (industrial dialogue) were also initiated, inviting the social partners to give their views on the policies that should be implemented.

According to the government, a well-developed and well-functioning digital infrastructure is a precondition for meeting the challenges linked to digitalization and to ensure that the policy strategy contributes to enhancing productivity and competitiveness, full employment and sustainable economic growth. The strategy is based on five main areas: digital competence, digital security, digital innovation, digital management and digital infrastructure. The report published by the Digitalization Commission highlighted a number of needs and submitted a number of recommendations (see SOU 2015, p. 109), namely, to further digitalize public administration and to adapt labour and consumer laws and social insurance to meet the digitalization challenges. The Commission recommended also that the Swedish work environment authority should define a concept for the digital work environment and provide guidelines regarding how the new environment should be treated in accordance with existing work-environment and working-time legislation.

Last but not least, the Digitalization Commission recommended favouring a strategy of skill-upgrading by further developing lifelong-learning facilities and IT education at university level. The social partners were asked to give their opinions on the Commission's proposal.

The two sides of industry have traditionally been positive towards structural changes and the introduction of new productivity-enhancing technologies. The social partners agree also that the necessary transformation of working conditions and employment relations owing to digitalization should mainly be the outcome of negotiations via the conclusion of collective agreements at the industry level, even though employers were also more inclined to initiate some labour law reforms (mainly of employment protection). As stressed by Bergström and Ismail (2019), it is interesting to note that digitalization has tended to reinforce established positions between the social partners and that the digitalization discourse has become an arena in which the social partners invoke old positions.

Trade unions use digitalization as a way of explaining the emergence of new forms of insecure employment relationships, such self-employment and fixed-term contracts. For employers' organizations, however, digitalization provides a rationale for why jobs may need to be shed and why labour law needs to be reformed. They both share the view, however, that digitalization creates new demands on workers in relation to skills and competences, and they also seem to agree upon the need to reform the structure and content of the Swedish education system to provide the skills and competences necessary to compete in a world of digitalization. This concerns the role of both higher education and secondary education, as well as discussions about new structures for adult education to facilitate career development and continuous or lifelong learning. Despite this paradox, the discourse on training and education is placed in the nexus of already established conflicts regarding how training and education should be financed and organized in the Swedish labour market. According to the trade unions, training should be provided by employers and be seen as part of continuing development at the workplace. Employers, however, argue that education should be provided by the state as a form of societal infrastructure and that workers have an individual responsibility for competence development to ensure their employability. Digitalization thus reconfirms and reinforces already established positions between social partners. That is, despite the novelty, the digitalization discourse becomes an arena for social partners to recall old positions. (Bergström and Ismail 2019, p. 33). 
As also stressed by Bergström and Ismail (2019) the tripartite industrial dialogue on digitalization initiated in 2015 by the Social Democratic government underscored the importance of developing a common platform for collaboration between the government and social partners. The main objective is to identify common challenges, as well as to create a basis for implementing government initiatives and policies. This tripartite industrial dialogue may from this perspective be considered successful because it has been continuous over a four-year period, involving a relatively large number of key actors. However, as noted by Bergström and Ismail (2019), the tripartite dialogue has, to date, not resulted in concrete policies, legal reforms or broad collective agreements. The industrial dialogue initiated by the government was mainly concerned with general strategies, in the form of exchanges of opinions rather than direct bargaining concerning specific policies, incentives or regulatory frameworks.

The digitalization process underlines the importance of skill-upgrading measures via lifelong-learning and education policies, as well as job transition measures facilitating the relocation of human resources and ensuring employability over the life course. In this context, there are strong reasons to believe that the structural changes related to further digitalization will be met within the framework of the prevailing bipartite social dialogue, and will mainly take the form, as in the past, of job security/transitional agreements.

Even though the tripartite dialogue on digitalization to date has not resulted in broad collective agreements, some interesting developments can be noted regarding platform work. Sweden constitutes an interesting illustration of the social partners' role and capacity in regulating the digital platform economy, as evidenced by the recent collective agreement (April 2021) concluded between the Swedish Federation of Transport (Transport Union) and Foodora (Food delivery digital labour platform). This agreement stipulates a minimum wage for cycle riders and guarantees an annual wage increase in line with transport industry agreement as well as entitlements to pensions and insurances in accordance with Transport's other collective agreements. Two digital labour platforms, Instajobs and Just arrived (personal and household services) are members of the Employer Association Competence Agency of Sweden (Kompetensföretag) and signatories of the Temporary Agency Collective Agreement. Reflecting the Swedish flexicurity model, this Agreement stipulates that permanent employment contracts constitute the norm, and guarantees that salaries are paid between assignments and that staffing consultants are entitled to the same benefits and rights as other employees, such as the right to paid holidays, study/ training and parental leave, as well as entitlements to occupational pensions.

\section{CONCLUSIONS}

Despite a significant decline in union density, Swedish trade unions and employer organizations remain the main actors responsible for labour market norms and regulations affecting the terms and conditions of employment. The capacity of the Swedish economy to adapt to societal and economic challenges is intimately related to its industrial relations system. The Swedish experience remains a good illustration of the positive productive role played by a developed bipartite social dialogue based on powerful and independent social partners, especially regarding the mitigation of potentially negative consequences of globalization, external macroeconomic shocks, rapid structural and technological 
change, and the transformation of the world of work. The Swedish flexicurity regime, based on negotiated flexibility, creates a favourable institutional environment for negotiated compromises aimed at balancing flexibility, security, efficiency and social justice in an open economy strongly exposed to international competition and growing economic turbulence. As illustrated by Case Study 2, the Swedish job security councils and transitional job agreements have played a fundamental role in alleviating the detrimental individual consequences of structural and technological changes, in particular by limiting long periods of unemployment, which we know are a crucial determinant of social exclusion and increased inequality. These collective agreements constitute a good illustration of the prevailing regime of flexicurity and negotiated flexibility, combining individual security for employees and flexibility for employers with regard to necessary restructuring and readjustment measures.

Similar to a majority of EU member states, over the past two decades Sweden has experienced a marked decline in union density, particularly among blue-collar workers. This threatens the long-term representativeness and legitimacy of blue-collar unions, as well as their autonomy and bargaining power. This development, if it continues, will compromise the long-term sustainability of the Swedish model of industrial relations and its ability to reconcile efficiency and social justice. The decrease in union density can be ascribed to policy reforms negatively affecting the Swedish Ghent system of unemployment insurance, as well as the substantial modifications in the world of work, particularly the rise of precarious employment related to changing employment protection and labour market deregulation. To counteract this development, Swedish trade unions have initiated several measures aimed at broadening their recruitment base. These include trying to reach vulnerable groups and atypical forms of employment (short-term contracts, temporary agency workers, solo self-employed and digital platform workers). In order to attract and retain members, unions have also developed new services and make increasing use of new digital technologies to reach new members. They have also introduced complementary insurance schemes (sickness and unemployment) limited to union members. It remains to be seen whether these measures will reverse the negative trends in union density.

The, by international standards, still high union density, high coverage rates of collective bargaining, and relatively centralized and coordinated multi-employer collective bargaining processes explain, to a large extent, the predominant role played by collective agreements in shaping the world of work in Sweden. Viewing developments over the past three decades, it can be seen that the Swedish industrial relations system and its bipartite nature have favoured the development of high-quality jobs, fair working conditions, decent wages and low inequality. The compressed wage structure, with high, collectively agreed, wage floors, has also promoted growth-enhancing structural change, limiting the development of low-skilled jobs and contributing to the development of a high-skilled, knowledge-intensive, economy. In effect, large investments in labour-saving technologies and research and development, the positive attitudes of trade unions towards the introduction of new technologies and productivity-enhancing technological change, as well as well-developed lifelong learning and training systems and active labour marker policies have limited job polarization, reinforced the competitiveness of the Swedish economy and promoted balanced growth and full employment. 


\section{NOTES}

* I would like to thank Anders Kjellberg for constructive and very helpful comments on a previous version of this chapter.

1. We use the ILO definition of social dialogue, which encompasses all types of negotiation, consultation or simply exchange of information between, or among, representatives of governments, employers and workers, on issues of common interest related to economic and social policy.

2. In 2018, Sweden counted around 670 nationwide collective agreements at the industry level.

3. The Swedish trade union landscape comprises three confederations: the Swedish Trade Union Confederation (Landsorganisation, LO) organizing blue-collar workers with 14 federations and around 1.23 million active members; the Swedish Confederation of Professional Employees (Tjänstemännens Centralorganisation, TCO) organizing white-collar workers (professionals and qualified employees), counted at the same date, 14 federations and around 1.1 million active members; and the Swedish Confederation of Professional Associations (Sveriges Akademikers Centralorganisation, Saco) organizing university graduate employees, which at the same date had 539000 active members affiliated to 23 federations (see Kjellberg 2019c; Mediation Office 2019). Sweden counted around 4.7 million dependent employees in 2018 (Statistics Sweden 2019).

4. Sweden has three main employer confederations. In the private sector is the Confederation of Swedish Enterprise (Svenskt Näringsliv, SN). It has two employer associations in the public sector: the Swedish Association of Local Authorities and Regions (Sveriges Kommuner och Regioner, SKR) for local authorities (covering more than 1 million employees, or 25 per cent of total employment in Sweden) and the Swedish Agency for Government Employers (Arbetsgivarverket, Agf), which has 240-member agencies in the central government sector (around 270000 employees). The Confederation of Swedish Enterprise is Sweden's largest and most influential business confederation in the private sector, representing 49 member organizations and 60000 member companies, with over 1.6 million employees. In 2018, around 65 per cent of the Confederation's member companies had fewer than ten employees, while only 2 per cent had 250 employees or more (see Table 14A.4 in the appendix).

5. As suggested by one of my colleagues, Anders Kjellberg, it should, however, be noted that since the early 1990 s the concertation role of the social partners in Sweden has been reduced. In the early 1990s the Swedish employers' confederation withdrew from representation in public authority boards and, consequently, the former system of representation of social partners in public authorities was abolished.

6. Namely, the Swedish Association of Local Authorities and Regions (Sveriges Kommuner och Regioner, SKR) for local authorities (with more than 1 million employees, or 25 per cent of total employment in Sweden) and the Swedish Agency for Government Employers (Arbetsgivarverket, Agf) with 240 member agencies in the central government sector (around 270000 employees).

7. In 2018, the employment rate (20-64 years of age) among the native population was 86.5 per cent (87.8 per cent for men and 85.2 per cent for women) compared with 70.1 per cent among the foreign-born population ( 74.5 per cent for men and 65.8 per cent for women). During the same period, the unemployment rate stood at 3.0 per cent among the native population, compared with 15.0 per cent among the foreign-born population. Also, the unemployment rate among young immigrants (15-24 years of age) is significantly higher (29.5 per cent in 2018) than that of their native counterparts (14 per cent at the same date).

8. The National Board of Health and Welfare, the Swedish Council for Higher Education, the Swedish National Agency for Higher Vocational Education and the Swedish Forest Agency. Together with the PES these agencies also took part in the in-depth tripartite talks.

9. Sweden does not have a statutory minimum wage and the social partners have always been opposed to state interference in the regulation of wage and working conditions.

10. The Swedish Federation IF Metall (Industrifacket Metall), affiliated to the LO confederation and organizing blue-collar workers in mechanical engineering, ironwork, chemicals, plastics, textiles/clothing and mining; the Swedish Federation of White-Collar Workers in Industry and Services (Unionen), affiliated to the TCO confederation; and the Swedish Association of Graduate Engineers (Sveriges Ingenjörer) affiliated to the Saco confederation. Three other LO federations joined the Industry Agreement, namely, the Swedish Paper Workers' Union (Pappers), the Swedish Union of Forestry, Wood and Graphical Workers (GS) and the Food Workers' Union (LIVS). Mainly procedural, the Industry Agreement was first concluded in 1997 and twice revised in 2011 and 2016, respectively. In 2020, the union signatories of the Industry Agreement will conclude new agreements on wages and working conditions, covering around 400000 workers.

11. By international standards, Sweden has comparatively few labour market conflicts (strikes and lockouts) (see Anxo 2018; Kjellberg 2019c).

12. The Saltsjöbaden Agreement (1938) established a series of regulations covering the roles of the various actors in the labour market, and accorded the social partners considerable room for manoeuvre in respect 
of wage policy. The Saltsjöbaden Agreement also influenced the organization and functioning of negotiations, and regulated industrial disputes by demanding prior agreement with the confederations in the event of disputes affecting more than 3 per cent of the workforce, thus guaranteeing industrial peace as soon as the collective agreements were concluded.

13. The Act on Union Representatives' Position at the Workplace (SFS 1974, p. 358), the Law on Codetermination in Working Life (SFS 1976, p. 580) and the Employment Protection Act (SFS 1982a, p. 80).

14. A total of 88 per cent among young people (aged 20-34) and 77 per cent among prime age workers (25-54 years old), see OECD (2019).

15. The highest female employment rate (20-64 years old) and senior employment rate (55-64 years old) in the Sweden were, respectively, 80.2 per cent and 78 per cent in 2018 . The corresponding figures for the EU were, respectively, 67.4 per cent and 58.7 per cent; see Eurostat (2020).

16. Low-wage earners are defined as those earning two-thirds or less of national median gross hourly earnings.

17. Owing, in particular, to a strong complementarity between skills and new technologies.

18. The propensity to join a trade union is traditionally higher in these two sectors.

19. According to Kjellberg's (2019b) calculations, if union density declines at the same pace in the future, overall union density will drop from 68 per cent in 2018 to 65 per cent in 2023 (from 60 to 56 per cent among blue-collar workers and from 73 to 69 per cent among white-collar workers).

20. The Swedish unemployment insurance system is a Ghent system, based on voluntary membership subsidized by the state. Different trade unions covering different industries administer the unemployment insurance funds.

21. To illustrate, between 2006 and 2009 the individual monthly unemployment insurance fees for construction workers increased from SEK116 (€11.9) to SEK455 (€46.6), for workers in engineering from SEK93 (€9.9) to SEK384 (€40.9) and for employees in hotels and restaurants from SEK97 (€9.9) to SEK430 (€44.0) (see Kjellberg 2015). If you add the normal affiliation fee for being a trade union member, the monthly cost increase was significant.

22. The share of the workforce covered by unemployment insurance decreased from 80 to 67 per cent between 2007 and 2009.

23. Previous economic recessions, in particular the deep economic crisis of the early 1990s, led to an increase in trade union membership, and also of union density (see Figures 14.1 and 14.2).

24. Two main reasons explain this change: new general elections and the reform of unemployment insurance that implied that a large number of wage earners, in particular low-paid or low-skilled employees with unstable employment conditions, lacked sufficient protection in the event of unemployment, which amplified the risk of social exclusion.

25. Up to now the only LO federation to accept the self-employed as members is the Federation of Musicians (Musikerförbundet). The main federation within the TCO accepting the self-employed is the Federation Union (600 000 members). Most Saco unions have self-employed persons as members since many occupations within Saco have a tradition of self-employment (for example, dentist, medical doctors, psychologists, lawyers, economists and graduate engineers).

26. As noted by Rönnmar and Numhauser-Henning (2012, p. 465): 'The Swedish law provides a rather broad scope for numerical flexibility, by way of the employer's possibilities to adapt the size of the workforce to the changing demands of the business and to dismiss employees for reasons of redundancy. ... and redundancy constitutes objective grounds of dismissal.'

27. It can be anything from simple advice, such as how to improve a curriculum vitae (CV), to more farreaching measures, such as participation in vocational training or education schemes, changing occupation or starting a business.

28. The employers finance the various activities by paying a contribution of 0.15 per cent to 0.3 per cent of the wage bill. All employees covered by these agreements are included in the activities, regardless of whether they are union members or not.

29. Section 5.2 relies heavily on the recent study conducted by Bergström and Ismail (2019).

\section{BIBLIOGRAPHY}

Anxo, D. (2015), 'The Swedish social model: resilience and success in turbulent times', in D. Vaughan-Whitehead (ed.), The European Social Model in Crisis. Is the European Model Losing its Soul? Cheltenham, UK and Northampton, MA, USA: Edward Elgar. 
Anxo, D. (2017), 'Turbulent time and beyond: the Swedish experience', in I. Guardiancich and O. Molina (eds), Talking through the Crisis: Social Dialogue and Industrial Relations Trends in Selected EU Countries, Geneva, International Labour Office, pp. 281-97.

Anxo, D. (2018), 'Shaping the future of work in Sweden: the crucial role of social partnership', in D. Vaughan-Whitehead (ed.), Reducing Inequalities in Europe. How Industrial Relations and Labour Policies Can Close the Gap, Cheltenham, UK and Northampton, MA, USA: Edward Elgar, pp. 519-54.

Anxo, D. (2019), 'Convergence towards better working and living conditions: the crucial role of industrial relations in Sweden', in D. Vaughan-Whitehead (ed.), Towards Convergence in Europe, Cheltenham, UK and Northampton, MA, USA: Edward Elgar and ILO, pp. 398-435.

Bergström O. and M. Ismail (2019), 'Digitalization and social dialogue in Sweden', Working Paper No. 2019-01, Diresoc Country report, WP1, accessed 11 November 2019 at http://diresoc.eu/wpcontent/uploads/2019/03/DIRESOC_Sweden-country-report.pdf.

Eurostat (2020), 'Employment statistics', accessed February 2020 at https://ec.europa.eu/eurostat/ statistics-explained/index.php/Employment_statistics.

Kjellberg, A. (2015), 'Växande Avgiftsskilnader i a-kassan och utveckling därefeter' ('Growing fees differential in U-founds and development thereafter'), Studies in Social Policy, Industrial Relations, Working Life and Mobility, Research Report No. 2014:1 Department of Sociology, Lund University, Lund.

Kjellberg, A. (2017), 'Self-regulation versus state regulation in Swedish industrial relations', in M. Rönnmar and J. Votinius (eds), Festskrift till Ann Numhauser-Henning, Lund: Juristförlaget i Lund, pp. 357-83.

Kjellberg, A. (2019a), 'Sweden: collective bargaining under the industry norm', in T. Müller, K. Vandaele and J. Waddington (eds), Collective Bargaining in Europe: Towards an Endgame, vol. 3, Brussels, ETUI, pp. 583-603.

Kjellberg, A. (2019b), 'Den svenska modellen i fara' ('The Swedish model in danger'), Arena Idé, accessed at https://arenaide.se/rapporter/den-svenska-modellen-fara/.

Kjellberg, A. (2019c), 'Kollektivavtalens täckningsgrad samt organisationsgraden hos arbetsgivarförbund och fackförbund' ('Collective agreement coverage and the degree of organization of employers' federations and unions'), Department of Sociology, Lund University, Lund.

Landsorganisationen i Sverige (LO) (2019), 'Facklig anslutning år 2019' ('Union density in 2019'), accessed September 2019 at https://www.lo.se/start/lo_fakta/facklig_anslutning_2019.

Mediation Office (2019), 'En sammanställning över organisationernas medlemsutveckling och täckningsgrad' ('A summary of member organisations and coverage levels'), accessed 13 December 2019 at http://www.mi.se/kollektivavtal-lagar/.

Muñoz de Bustillo Llorente, R. (2020), 'Digitalization and social dialogue: challenges, opportunities and responses', in D. Vaughan-Whitehead and Y. Ghellab (eds), Enhancing Social Partners' and Social Dialogue Roles and Capacity in the New World Of Work, Geneva: ILO and University of Salamanca, pp. 101-33.

Organisation for Economic Co-operation and Development (OECD) (2019), Negotiating Our Way Up: Collective Bargaining in a Changing World of Work, Paris, OECD, doi:10.1787/1fd2da 34-en.

Paccagnella, M. (2014), 'Skill and wage inequality, evidence from PIACC', OECD Directorate for Education and Skills, Paris.

Rönnmar, M. And A. Numhauser-Henning (2012), 'Swedish employment protection in times of flexicurity policies and economic crisis', in International Journal of Comparative Labour Law and Industrial Relations, 28 (4), 443-68.

Sjögren-Lindquist, G. and E. Wadensjö (2006), 'Complementary benefits in connection with loss of income and their effect on the work principle', in J. Olofsson and M. Zavisic (eds), Routes to a More Open Labour Market, Stockholm: National Institute for Working Life, pp. 129-36.

Statens offentliga utredningar (SOU) (2015), Digitaliseringens transformerande kraft (The Transforming Power of Digitalisation. Way of the Future, Stockholm: Elanders Sverige AB.

Statistics Sweden (2019), 'Labour Force Survey', accessed 14 January 2020 at https://www.scb. se/hitta-statistik/statistik-efter-amne/arbetsmarknad/arbetskraftsundersokningar/arbetskraft 
sundersokningarna-aku/pong/tabell-och-diagram/icke-sasongrensade-data/grundtabeller-aku1574-ar-ar/.

Svensk forfattningssamling (SFS) (1974), 'Lag (SFS 1974:358) om facklig förtroendemans ställning på arbetsplatsen' ('Law on union representatives' position at the workplace'), accessed 12 September 2019 at https://www.riksdagen.se/sv/dokument-lagar/dokument/ svensk-forfattningssamling/lag-1974358-om-facklig-fortroendemans_sfs-1974-358.

Svensk forfattningssamling (SFS) (1976), 'Lag (SFS 1976:580) om medbestämmande i arbetslivet' ('Law on co-determination in working life'), accessed 12 September 2019 at https://www.riksdagen.se/sv/Dokument-Lagar/Lagar/Svenskforfattningssamling/Lag-1976580om-medbestamman_sfs-1976-580/.

Svensk forfattningssamling (SFS) (1982a), 'Lag (SFS 1982:80) om anställningsskydd, LAS' ('Employment Protection Act'), accessed 12 September 2019 at https://www.riksdagen.se/sv/ Dokument-Lagar/Lagar/Svenskforfattningssamling/Lag-198280-om-anstallningss_sfs-1982-80/. Svensk forfattningssamling (SFS) (1982b), 'Lag (SFS 1982:673) Arbetstidslag' ('Working Time Act'), accessed 12 September 2019 at https://www.riksdagen.se/sv/dokument-lagar/dokument/ svensk-forfattningssamling/arbetstidslag-1982673_sfs-1982-673.

Visser, J. (2019), 'ICTWSS database, version 6.1', November, Amsterdam Institute for Advanced Labour Studies, University of Amsterdam, Amsterdam. 


\section{APPENDIX}

Table 14A.1(a) Trends in the number of trade union active members, by confederation

\begin{tabular}{|c|c|c|c|c|c|c|c|c|c|}
\hline Sector & 1990 & 2000 & 2005 & 2006 & 2010 & 2015 & 2018 & $\begin{array}{c}\text { Var. } \\
\text { 2006-18 }\end{array}$ & $\begin{array}{c}\text { Var. } \\
\text { 2018-1990 }\end{array}$ \\
\hline LO & 1962416 & 1753075 & 1586927 & 1564409 & 1318343 & 1271129 & 1232815 & $5-331594$ & -729601 \\
\hline TCO & 1144218 & 1045473 & 1039870 & 1025990 & 962629 & 1060977 & 1097415 & $5 \quad 71425$ & -46803 \\
\hline Saco & 260127 & 370462 & 418648 & 424621 & 454110 & 491477 & 538947 & 114326 & 278820 \\
\hline All & 3366761 & 3169010 & 3045445 & 3015020 & 2735082 & 2823583 & 2869177 & $7-145843$ & -497584 \\
\hline
\end{tabular}

\section{Notes:}

LO - Swedish Trade Union Confederation, organizing blue-collar workers (Landsorganisation. LO).

TCO - Confederation of Professional Employees (Tjänstemännens Centralorganisation, TCO) organizing white-collar workers (professionals and qualified employees).

Saco - Swedish Confederation of Professional Associations (Sveriges Akademikers Centralorganisation) organizing university graduate employees.

Source: Kjellberg (2019c).

Table 14A.1(b) Trends in union member shares by confederation, LO, TCO and Saco (percentage)

\begin{tabular}{rlrr}
\hline & LO & TCO & Saco \\
\hline 1975 & 63.5 & 32.1 & 4.4 \\
1980 & 62.6 & 31.7 & 5.7 \\
1985 & 60.2 & 33.3 & 6.6 \\
1990 & 58.3 & 34.0 & 7.7 \\
1995 & 57.4 & 33.7 & 8.9 \\
2005 & 52.1 & 34.1 & 13.7 \\
2010 & 48.2 & 35.2 & 16.6 \\
2015 & 45.0 & 37.6 & 17.4 \\
2018 & 43.0 & 38.2 & 18.8 \\
\hline
\end{tabular}

Notes:

LO - Swedish Trade Union Confederation, organizing blue-collar workers (Landsorganisationen. LO).

TCO - Confederation of Professional Employees (Tjänstemännens Centralorganisation, TCO) organizing white-collar workers (professionals and qualified employees).

Saco - Swedish Confederation of Professional Associations (Sveriges Akademikers Centralorganisation) organizing university graduate employees.

Source: Kjellberg (2019c). 
Table 14A.2 Union density by age, gender and ethnicity, Sweden, 1990-2018 (percentage)

\begin{tabular}{lccccccccc}
\hline & 1990 & 2000 & 2006 & 2008 & 2010 & 2015 & 2018 & $\begin{array}{l}\text { Var. 2018/1990 } \\
\text { percentage } \\
\text { points }\end{array}$ & $\begin{array}{l}\text { Var. 2018/2006 } \\
\text { percentage } \\
\text { points }\end{array}$ \\
\hline Age & & & & & & & & & \\
$16-24$ & 62 & 52 & 46 & 36 & 34 & 35 & 36 & -26 & -10 \\
$25-29$ & 78 & 74 & 68 & 61 & 60 & 59 & 58 & -20 & -10 \\
$30-44$ & 85 & 82 & 77 & 72 & 73 & 70 & 68 & -17 & -9 \\
$45-64$ & 88 & 88 & 85 & 81 & 80 & 79 & 77 & -11 & -8 \\
$16-64$ & 81 & 81 & 77 & 71 & 71 & 69 & 68 & -13 & -9 \\
\hline Gender & & & & & & & & & -10 \\
Men & 80 & 78 & 74 & 68 & 68 & 66 & 64 & -16 & -8 \\
Women & 83 & 83 & 80 & 74 & 75 & 73 & 72 & -11 & -6 \\
\hline Ethnicity & & & & & & & & & -16 \\
Natives & - & - & 77 & 72 & 72 & 71 & 71 & - & \\
Foreign-born & - & - & 74 & 67 & 67 & 61 & 58 & - & \\
\hline
\end{tabular}

Source: Kjellberg (2019c).

Table 14A.3 Trends in union density by industries, Sweden, 1990-2018 (variation in percentage points)

\begin{tabular}{lllllll}
\hline Sector & 199019962006200820102018 Var. & Var. & Var. & Var. \\
& & $2008-2006$ & 2010-2008 & 2018-2006 & 1990-2018
\end{tabular}

\begin{tabular}{|c|c|c|c|c|c|c|c|c|c|c|}
\hline \multicolumn{11}{|c|}{ Manual workers/blue-collars } \\
\hline $\begin{array}{l}\text { Manufacturing } \\
\text { industry }\end{array}$ & 91 & 92 & 89 & 88 & 85 & 81 & 81 & 79 & -9 & -12 \\
\hline Construction & 91 & 92 & 89 & 88 & 85 & 81 & 81 & 79 & -9 & -12 \\
\hline Retail & 91 & 92 & 89 & 88 & 85 & 81 & 81 & 79 & -9 & -12 \\
\hline $\begin{array}{l}\text { Hotel and } \\
\text { restaurants }\end{array}$ & 91 & 92 & 89 & 88 & 85 & 81 & 81 & 79 & -9 & -12 \\
\hline Private services & 91 & 92 & 89 & 88 & 85 & 81 & 81 & 79 & -9 & -12 \\
\hline Public services & 91 & 92 & 89 & 88 & 85 & 81 & 81 & 79 & -9 & -12 \\
\hline All & 91 & 92 & 89 & 88 & 85 & 81 & 81 & 79 & -9 & -12 \\
\hline \multicolumn{11}{|c|}{ Non-manual workers/white-collars } \\
\hline $\begin{array}{l}\text { Manufacturing } \\
\text { industry }\end{array}$ & 82 & 83 & 80 & 75 & 77 & 78 & -5 & 2 & -2 & -4 \\
\hline Retail & 60 & 63 & 62 & 56 & 61 & 65 & -6 & 5 & +3 & +5 \\
\hline
\end{tabular}


Table 14A.3 (continued)

\begin{tabular}{|c|c|c|c|c|c|c|c|c|c|c|}
\hline Sector & 1990 & 1996 & 2006 & 2008 & 2010 & 2018 & $\begin{array}{l}\text { Var. } \\
\text { 2008-2006 }\end{array}$ & $\begin{array}{l}\text { Var. } \\
\text { 2010-2008 }\end{array}$ & $\begin{array}{l}\text { Var. } \\
2018-2006\end{array}$ & $\begin{array}{l}\text { Var. } \\
\text { 1990-2018 }\end{array}$ \\
\hline Private services & 66 & 73 & 65 & 60 & 63 & 65 & -5 & 3 & 0 & -1 \\
\hline Public services & 94 & 93 & 89 & 85 & 86 & 82 & -4 & 1 & -7 & -12 \\
\hline All & 81 & 83 & 77 & 72 & 73 & 73 & -5 & 1 & -4 & -8 \\
\hline $\begin{array}{l}\text { All sectors/ } \\
\text { occupations }\end{array}$ & 82 & 84 & 77 & 71 & 71 & 68 & -6 & 0 & -9 & -14 \\
\hline
\end{tabular}

Source: Mediation Office (2019) and Kjellberg (2019).

Table 14A.4 Swedish Confederation of Enterprise (Svenskt Näringsliv) number of affiliated enterprises and number of employees, 2018

\begin{tabular}{lcccc}
\hline Number of employees & Number of companies & Share $(\%)$ & Number of employees & Share (\%) \\
\hline 0 & 9279 & 15.6 & - & - \\
$1-9$ & 28107 & 47.1 & 115490 & 6.3 \\
$10-49$ & 16792 & 28.2 & 355117 & 19.3 \\
$50-249$ & 4430 & 7.4 & 441228 & 24.0 \\
$250-499$ & 515 & 0.9 & 179530 & 9.8 \\
$500-$ & 495 & 0.8 & 748959 & 40.7 \\
All & 59618 & 100.0 & 1840324 & 100.0 \\
\hline
\end{tabular}

Source: Mediation Office (2019).

Table 14A.5 Share of dependent employees in companies/organizations affiliated to an employer organization, 1995-2017 (percentage)

\begin{tabular}{lrrrrrc}
\hline Sector & 1995 & 2005 & 2007 & 2010 & 2017 & Var. 2010-17 \\
\hline Private & 77 & 78 & 77 & 80 & 82 & +5 \\
Public & 100 & 100 & 100 & 100 & 100 & 0 \\
All & 86 & 86 & 84 & 87 & 88 & +2 \\
\hline
\end{tabular}

Source: Mediation Office (2019) and Kjellberg (2019c). 
Table 14A.6 Coverage rate of collective bargaining, Sweden, 1995-2017 (percentage of dependent employees)

\begin{tabular}{lrrrrrc}
\hline Sector & 1995 & 2005 & 2007 & 2010 & 2017 & Var. 1995-2017 \\
\hline Private & 90 & 89 & 86 & 84 & 84 & -6 \\
Public & 100 & 100 & 100 & 100 & 100 & 0 \\
All & 94 & 93 & 91 & 89 & 89 & -5 \\
\hline
\end{tabular}

Source: Mediation Office (2019) and Kjellberg (2019c).

Table 14A.7 Share of manual/blue-collar workers and non-manual/white-collar workers covered by collective agreements, 2017

\begin{tabular}{lccr}
\hline Categories & Private sector & Public sector & All \\
\hline Blue collars & 95 & 100 & 96 \\
White collars & 75 & 100 & 84 \\
All & 83 & 100 & 89 \\
\hline
\end{tabular}

Source: Mediation Office (2019). 